Cite this: Dalton Trans., 2014, 43, 317

Received 3rd August 2013,

Accepted 19th September 2013

DOI: $10.1039 / c 3 d t 52112 \mathrm{e}$

www.rsc.org/dalton

\section{Mineralization of DNA into nanoparticles of hydroxyapatite}

\author{
Oscar Bertran, $\dagger^{\mathrm{a}}$ Luis J. del Valle, $\uparrow^{\mathrm{b}}$ Guillermo Revilla-López, ${ }^{\mathrm{b}}$ Gustavo Chaves, ${ }^{\mathrm{b}}$ \\ Lluís Cardús, ${ }^{b}$ María T. Casas, ${ }^{b}$ Jordi Casanovas, ${ }^{c}$ Pau Turon, ${ }^{* d}$ Jordi Puiggalí*b,e and \\ Carlos Alemán*b,e
}

\begin{abstract}
Encapsulation of DNA into hydroxyapatite (HAp) has been investigated using a rational approach that involves computer simulation and experimental techniques. The temporal evolution of the radial distribution functions derived from atomistic molecular dynamics simulations of $\mathrm{Ca}^{2+}, \mathrm{PO}_{4}{ }^{3-}$ and $\mathrm{OH}^{-}$-containing aqueous solutions in the presence and absence of B-DNA has been used to conclude that the backbone of the double helix acts as a template for HAp growth. More specifically, results reveal the formation of calcium phosphate clusters at the first stages of the simulations, which subsequently reorganize to nucleate HAp. This effect is produced in the absence and, especially, presence, of DNA indicating that the biomolecules do not inhibit but even promote mineral growth. Furthermore, computer simulations suggest that the diffusion of the $\mathrm{OH}^{-}$anions through the inorganic solution is the limiting step for the nucleation of the biomineral. Nanocapsules and crystalline nanorods of HAp containing DNA molecules inside have been prepared by mixing solutions containing $\mathrm{Ca}^{2+}$ and $\mathrm{PO}_{4}{ }^{3-}$ ions with fish sperm DNA at high $\mathrm{pH}$. The dimensions and morphology of such nanostructures have been examined by transmission electron microscopy, while the characterization of the biomineral has been focused on the identification of DNA inside HAp using infrared, X-ray photoelectron and UV-vis spectroscopies, as well as gel electrophoresis. The biominerals reported in this work are important for biomedical applications requiring the protection of DNA from aggressive environmental conditions.
\end{abstract}

\section{Introduction}

Hydroxyapatite (HAp), $\mathrm{Ca}_{10}\left(\mathrm{PO}_{4}\right)_{6}(\mathrm{OH})_{2}$, is a complex mineral which is becoming increasingly important as a candidate for use as a biomaterial. HAp is the main mineral phase of mammalian tooth enamel and bone, ${ }^{1}$ where it grows as nano-sized mineral platelets at nucleating sites on a protein template. ${ }^{2,3}$ More specifically, very thin HAp platelets adopt an ordered arrangement within and around collagen fibrils, the mineral being aligned with its $c$-axis along the fibril. ${ }^{2}$ HAp-collagen composites are biodegradable and good matrices for bone cell

\footnotetext{
${ }^{a}$ Departament de Física Aplicada, EEI, Universitat Politècnica de Catalunya, Pça. Rei 15, 08700 Igualada, Spain

${ }^{b}$ Departament d'Enginyeria Quimica, E. T. S. d'Enginyeria Industrial de Barcelona, Universitat Politècnica de Catalunya, Diagonal 647, 08028 Barcelona, Spain ${ }^{c}$ Departament de Química, Escola Politècnica Superior, Universitat de Lleida, c/Jaume II $n^{\circ}$ 69, Lleida E-25001, Spain

${ }^{d}$ B. Braun Surgical S.A. Carretera de Terrasa 121, 08191 Rubi, Barcelona, Spain. E-mail:pau.turon@bbraun.com

${ }^{e}$ Center for Research in Nano-Engineering, Universitat Politècnica de Catalunya, Campus Sud, Edifici C', C/Pasqual $i$ Vila s/n, Barcelona E-08028, Spain.

E-mail: jordi.puiggali@upc.edu, carlos.aleman@upc.edu

$\dagger$ These authors contributed equally to this work.
}

attachment and proliferation, as well as new bone formation. ${ }^{4}$ Several non-collagenous proteins have been also associated with HAp. Specifically, the growth of the bone is controlled by naturally evolved proteins, ${ }^{5-7}$ and malfunction of these proteins may lead to severe skeletal diseases. ${ }^{8}$

In the last few years interactions between HAp and DNA are believed to play an important role in different fields, including the biomedical one. ${ }^{9,10}$ For example, recent spectroscopic studies showed the contribution of vibrational modes of DNA, phospholipids and protein appears in HAp microcalcifications formed in the organism. ${ }^{9}$ More recently, HAp nanoparticles (NPs) have been used as non-viral gene carriers. ${ }^{10-13}$ Thus, DNA-HAp NPs complexes were found to cross cell membranes, integrating into the cell genome. In a very recent study, Brundin $e t a l .{ }^{14}$ showed a specific binding affinity of HAp for DNA. These same authors found that HAp-bound DNA is more resistant to decay and less susceptible to degradation by serum and nucleases, which may account for the long-term persistence of DNA in bone and tooth. ${ }^{14}$

The direct encounter between DNA and HAp in biological systems suggests that investigation of the interaction between these two materials and particularly, of the formation of biominerals through the nucleation of HAp at a DNA template 
would be very useful for the development of novel strategies for gene therapy. Thus, biomineralization would facilitate DNA protection by the surrounding inorganic material. Amazingly, the number of studies devoted to examining the interaction between HAp and DNA is still very scarce. In an early study, Jordan et al. $^{15}$ reported on DNA-calcium phosphate co-precipitation for transfection purposes, even though such co-precipitation was described only in a narrow range of physicochemical conditions. More recently, Okazaki et al. ${ }^{16}$ investigated the effect of DNA on the crystal growth of HAp by synthesizing the mineral in the presence of the biomolecule. Those authors reported that DNA inhibits the HAp crystal growth, indicating that DNA molecules are not in the HAp structure but adsorbed at the surface. Finally, in a very recent study we used molecular modeling tools to examine the structure and stability of biominerals in which DNA molecules are embedded into HAp nanopores. ${ }^{17}$ Results indicated that duplexes of DNA adopting a B double helix can be encapsulated inside nanopores of HAp without undergoing significant conformational distortions.

On the basis of these observations, in this work we investigate the encapsulation of DNA into HAp nanoparticles using a rational design approach that combines theoretical and experimental methodologies. Atomistic molecular dynamics (MD) simulations of B-DNA immersed in an inorganic solution show the rapid formation of calcium phosphate clusters at the biomolecule template. The temporal evolution of these clusters suggests the growing of HAp around the DNA matrix. Although 50 ns trajectories only represent the initial stages of nucleation of HAp around the DNA template, analyses support the view that the biomolecules promote, or at least does not inhibit, mineral growth. The inorganic solutions used for the simulations have been experimentally applied to fabricate nanocapsules and crystalline nanorods with DNA inside. Corroboration of this experimental achievement and characterization of the biomineral after the removal of superficially adsorbed DNA by enzymatic digestion were carried out through transmission electron microscopy (TEM), infrared spectroscopy (FTIR), X-ray photoelectron spectroscopy (XPS), UV-vis spectroscopy and gel electrophoresis.

\section{Methods}

\section{Computational methods}

The simulation system consisted of the Dickerson's dodecamer (5'-CGCGAATTCGCG-3'), which is a well-known sequence that adopts a B-DNA double helix, ${ }^{18} 955 \mathrm{Ca}^{2+}$ ions, $567 \mathrm{PO}_{4}{ }^{3-}$ ions, 189 $\mathrm{OH}^{-}$ions, and 29523 water molecules. In addition, simulations of a system made of $945 \mathrm{Ca}^{2+}$ ions, $567 \mathrm{PO}_{4}{ }^{3-}$ ions, $189 \mathrm{OH}^{-}$ions and 29554 water molecules were carried out to get more insights on the role of the B-DNA template in mineral growth.

MD simulations in NPT conditions (constant number of particles, temperature of $298 \mathrm{~K}$ and pressure of $1 \mathrm{~atm}$ ) were performed using the NAMD $2.6^{19}$ code. The potential energy was computed using the Amber force-field. ${ }^{20}$ All force-field parameters for DNA as well as the phosphate and hydroxyl groups were extracted from Amber ff03. ${ }^{21}$ It should be noted that the ff03 parameters are identical to the ff99-SB ${ }^{22}$ ones for nucleic acids, phosphate and hydroxyl groups. Force-field parameters of $\mathrm{Ca}^{2+}$ were extracted from the work reported by Bradbrook et $a .^{23}$ The ability of this set of force-field parameters to reproduce the inorganic-organic interactions found in biominerals was recently proved. ${ }^{17}$ The density of water in the simulation box was $1.00 \mathrm{~g} \mathrm{~cm}^{-3}$ at a temperature of $298 \mathrm{~K}$. The water molecules were represented using the TIP3P model. ${ }^{24}$

The initial simulation box $\left(92.0 \times 91.5 \times 108.0 \AA^{3}\right)$ was equilibrated using the following strategy. Before any MD trajectory, 5000 steps of energy minimization were performed to relax conformational and structural tensions. Next, different consecutive rounds of short MD runs were performed to equilibrate the density, temperature, and pressure. First, solvent and ions were thermally relaxed by three consecutive runs, while the B-DNA was kept frozen: 0.5 ns of NVT-MD (volume conserved) at $500 \mathrm{~K}$ were used to homogeneously distribute the solvent and ions in the box. After this, $0.5 \mathrm{~ns}$ of isothermal $(298 \mathrm{~K})$ and $0.5 \mathrm{~ns}$ of isobaric (1 atm and $298 \mathrm{~K}$ ) relaxation were run. Finally, all the atoms of the system were submitted to $0.15 \mathrm{~ns}$ of steady heating until the target temperature was reached $(298 \mathrm{~K}), 0.25 \mathrm{~ns}$ of NVT-MD at $298 \mathrm{~K}$ (thermal equilibration), followed by $0.5 \mathrm{~ns}$ of density relaxation (NPT-MD).

Atom pair distance cut-offs were applied at $16.0 \AA$ to compute the van der Waals interactions. In order to avoid discontinuities in the Lennard-Jones potential, a switch function was applied to allow a continuous decay of energy when the atom pair distances are larger than 14.0 ̊. For electrostatic interactions, we computed the non-truncated electrostatic potential throughout Ewald Summations. ${ }^{25}$ The real space term was determined by the van der Waals cut-off (16 ̊), while the reciprocal term was estimated by interpolation of the effective charge into a charge mesh with a grid thickness of 5 points per volume unit, i.e. Particle-Mesh Ewald (PME) method. ${ }^{25}$ Both temperature and pressure were controlled by the weak coupling method, the Berendsen thermobarostat. ${ }^{26}$ The relaxation times used for the coupling were 1 and $10 \mathrm{ps}$ for temperature and pressure, respectively. Bond lengths were constrained using the SHAKE algorithm ${ }^{27}$ with a numerical integration step of 1 fs. Periodic boundary conditions were applied using the nearest image convention, and the nonbonded pair list was updated every 1000 steps (1 ps). The end of the density relaxation simulation was the starting point of the production simulations presented in this work, which were 50 and 25 ns long for the system with and without the DNA template, respectively. The coordinates of all the production runs were saved every 1000 steps (1 ps interval).

\section{Experimental methods}

\section{Materials}

The materials used in the present work included fish sperm DNA, DNase I (bovine pancreas, >400 Kunitz units per mg), 
hexadecyltrimethylammonium bromide (CTBA), calcium nitrate $\left[\mathrm{Ca}\left(\mathrm{NO}_{3}\right)_{2} \cdot 4 \mathrm{H}_{2} \mathrm{O}\right]$, diammonium hydrogen phosphate $\left[\left(\mathrm{NH}_{4}\right)_{2} \mathrm{HPO}_{4}\right]$, ethylenediaminetetraacetic acid (EDTA), $\mathrm{NH}_{4} \mathrm{OH}, \mathrm{HCl}, \mathrm{NaCl}$, ethanol and deionized water. Fish sperm DNA, DNase I and CTBA were purchased from Sigma-Aldrich. Other reagents were provided by Panreac. All chemicals were of analytical grade and were used without further modification and purification.

\section{Synthesis of HAp-DNA nanocrystals}

$0.1 \mathrm{~g}$ of fish sperm DNA were added to $15 \mathrm{~mL}$ of a $0.3 \mathrm{M}$ $\left(\mathrm{NH}_{4}\right)_{2} \mathrm{HPO}_{4}$ solution in de-ionized water. The $\mathrm{pH}$ of such solution was previously adjusted to 10 with aqueous ammonia. The mixture was added drop-wise (rate of $2 \mathrm{~mL} \mathrm{~min}^{-1}$ ) and under agitation (400 rpm) to $25 \mathrm{~mL}$ of $0.3 \mathrm{M} \mathrm{Ca}\left(\mathrm{NO}_{3}\right)_{2}$ solution in de-ionized water and the appropriate amount of aqueous ammonia to adjust $\mathrm{pH}$ to 10 . Temperature was maintained at $40{ }^{\circ} \mathrm{C}$ during the addition process. After that, the reaction mixture was stirred at $80^{\circ} \mathrm{C}$ for $1.5 \mathrm{~h}$ and then naturally cooled to room temperature. The resultant suspension was aged for $24 \mathrm{~h}$ at room temperature. Then, the precipitate was separated by centrifugation and washed sequentially with de-ionized water and a 60/40 v/v mixture of ethanol-water (twice). A white powder was obtained after freeze-drying. The same protocol without the addition of fish sperm DNA was followed to get HAp nanocrystals, which were used as a control.

\section{Synthesis of HAp-DNA nanocapsules}

$0.382 \mathrm{~g}$ of fish sperm DNA were added to $5 \mathrm{~mL}$ of a $0.5 \mathrm{mM}$ $\mathrm{Ca}\left(\mathrm{NO}_{3}\right)_{2}$ solution in ethanol containing ammonia to adjust the $\mathrm{pH}$ to 11 . Specifically, the $\mathrm{DNA} / \mathrm{Ca}^{2+}$ ratio was $0.15 \mathrm{~g}$ $\mathrm{mmol}^{-1}$. The mixture was quickly added under agitation $(400 \mathrm{rpm})$ to $3 \mathrm{~mL}$ of $0.5 \mathrm{mM}\left(\mathrm{NH}_{4}\right)_{2} \mathrm{HPO}_{4}$ solution in de-ionized water and $0.5 \mathrm{mg}$ of CTAB surfactant (calculated to be half the value of the critical micellar concentration, CMC). The mixture was maintained under agitation at room temperature for $1 \mathrm{~h}$ and subsequently allowed to stand overnight at $37^{\circ} \mathrm{C}$. The precipitate was separated by centrifugation and washed sequentially with de-ionized water and a 60/40 v/v mixture of ethanol-water (twice). A white powder was obtained after freeze-drying. The same protocol without the addition of fish sperm was followed to get HAp nanocapsules, which were used as a control.

\section{Transmission electron microscopy (TEM)}

A Philips TECNAI 10 electron microscope was used and operated at $80 \mathrm{kV}$ for a bright field mode. Micrographs were taken with an SIS MegaView II digital camera. Nanocrystals were recovered from the mother liquor by centrifugation, repeatedly washed with water and ethanol and deposited on carboncoated grids. Nanocapsules were directly recovered from the highly diluted synthesis medium.

\section{FTIR spectroscopy}

Infrared absorption spectra were recorded from powder samples with a Fourier Transform FTIR 4100 Jasco spectrometer in the $1800-800 \mathrm{~cm}^{-1}$ range. A Specac model MKII
Golden Gate attenuated total reflection (ATR) equipment with a heated Diamond ATR Top-Plate was used.

\section{X-ray photoelectron microscopy (XPS)}

XPS analyses were performed in a SPECS system equipped with a high-intensity twin-anode X-ray source XR50 of $\mathrm{Mg} / \mathrm{Al}$ (1253 eV/1487 eV) operating at $150 \mathrm{~W}$, placed perpendicular to the analyzer axis, and using a Phoibos 150 MCD-9 XP detector. The X-ray spot size was $650 \mu \mathrm{m}$. The pass energy was set to 25 and $0.1 \mathrm{eV}$ for the survey and the narrow scans, respectively. Charge compensation was achieved with a combination of electron and argon ion flood guns. The energy and emission current of the electrons were $4 \mathrm{eV}$ and $0.35 \mathrm{~mA}$, respectively. For the argon gun, the energy and the emission current were $0 \mathrm{eV}$ and $0.1 \mathrm{~mA}$, respectively. The spectra were recorded with a pass energy of $25 \mathrm{eV}$ in $0.1 \mathrm{eV}$ steps at a pressure below $6 \times 10^{-9}$ mbar. These standard conditions of charge compensation resulted in a negative but perfectly uniform static charge. The C1s peak was used as an internal reference with a binding energy of $284.8 \mathrm{eV}$. High-resolution XPS spectra were acquired by Gaussian-Lorentzian curve fitting after s-shape background subtraction. The surface composition was determined using the manufacturer's sensitivity factors.

\section{UV-Vis spectroscopy}

A UV-3600 (Shimadzu) UV-Vis-NIR spectrophotometer controlled by the UVProbe 2.31 software was used to record the UV-Vis spectra of HAp-DNA nanoparticles at room temperature, in the 200-400 nm range, with a bandwidth of $0.2 \mathrm{~nm}$ and a scan speed of $600 \mathrm{~nm} \mathrm{~min}^{-1}$. Spectra were recorded from aqueous suspensions of $0.5 \mathrm{mg}$ of HAp-DNA nanoparticles in $1 \mathrm{~mL}$ of sterile milliQ water. Spectra were also acquired after dissolution of HAp-DNA nanoparticles by the addition of $100 \mu \mathrm{L}$ of an acid medium $(100 \mathrm{mM} \mathrm{HCl}$ and $50 \mathrm{mM} \mathrm{NaCl})$ in the cuvette. Samples were homogenized by pipetting and maintained at room temperature for 5-10 $\mathrm{min}$ before recording the spectra. The same procedure was followed to analyze HAp-DNA nanoparticles previously digested overnight with deoxyribonuclease which was used to eliminate the adsorbed DNA on the nanoparticle surface. Samples were recovered after digestion by centrifugation, washed twice with deionized water and re-suspended in $1 \mathrm{~mL}$ of deionized water. Spectra were recorded from this aqueous suspension and from the dissolution attained after the addition of $100 \mu \mathrm{L}$ of the acid medium.

\section{Gel electrophoresis}

Five samples were prepared for analysis by agarose gel electrophoresis: HAp nanoparticles, HAp-DNA nanoparticles before and after dissolution with EDTA and deoxyribonuclease digested HAp-DNA nanoparticles before and after dissolution with EDTA. This was performed by adding $5 \mu \mathrm{L}$ of a $250 \mathrm{mM}$ solution of EDTA. In each case, $25 \mu \mathrm{L}$ of an aqueous dispersion of the selected HAp-DNA nanoparticles $\left(10 \mu \mathrm{g} \mu \mathrm{L}^{-1}\right)$ were mixed with an aliquot $(5 \mu \mathrm{L})$ of $6 \times$ gel loading buffer. Subsequently, an aliquot of $15 \mu \mathrm{L}$ was introduced in the well of a 
$1 \%$ agarose gel containing ethidium bromide $\left(0.5 \mu \mathrm{g} \mathrm{mL} \mathrm{m}^{-1}\right.$ of gel) in $1 \times$ tris-borate-EDTA buffer (TBE).

\section{Results and discussion}

\section{Computational design}

In an early study Okazaki et al. ${ }^{16}$ indicated that DNA inhibits the crystal growth of HAp, which makes the formation of biominerals through the encapsulation of the biomolecule difficult. In order to investigate this feature, the temporal evolution of stoichiometric inorganic solutions of $\mathrm{Ca}^{2+}, \mathrm{PO}_{4}{ }^{3-}$ and $\mathrm{OH}^{-}$ions in the presence and absence of B-DNA has been investigated using MD simulations. The former and latter systems were simulated for 50 and $25 \mathrm{~ns}$, respectively, to gain insights not only from the clustering process but also from the mineral (or crystal) nucleation process, if it exists. Fig. 1 and 2 show the distribution of $\mathrm{Ca}^{2+}, \mathrm{PO}_{4}{ }^{3-}$ and $\mathrm{OH}^{-}$ions at selected snapshots extracted from the simulations in the presence and absence of B-DNA, respectively. As can be seen, the DNA favors the formation of embryonic clusters surrounding the double helix from the first stages of the MD simulation (i.e. after $1 \mathrm{~ns}$ ). These initial clusters mainly involve $\mathrm{Ca}^{2+}$ and $\mathrm{PO}_{4}{ }^{3-}$ ions, the incorporation of $\mathrm{OH}^{-}$anions being apparently very scarce at such an earlier part of the trajectory. Snapshots recorded after 25 and 50 ns of simulation show not only the incorporation of $\mathrm{OH}^{-}$anions, but also a change in the distribution of the $\mathrm{Ca}^{2+}$ and $\mathrm{PO}_{4}{ }^{3-}$ clustering. This feature suggests that DNA may act as a stable nucleating template for the
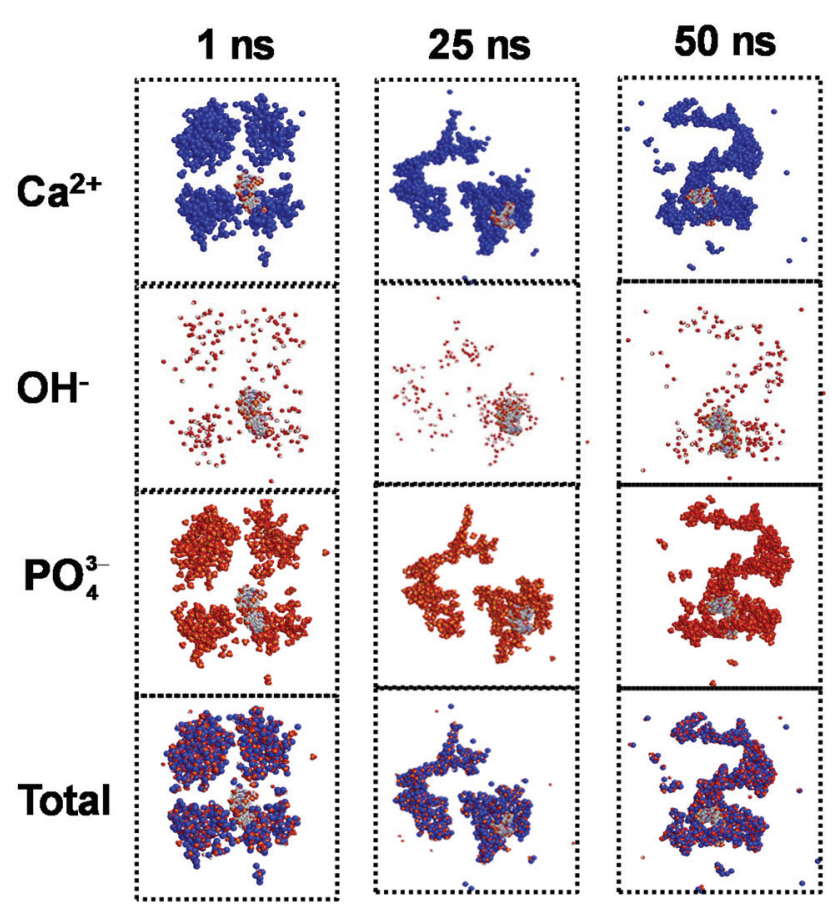

Fig. 1 Distribution of $\mathrm{Ca}^{2+}, \mathrm{PO}_{4}{ }^{3-}$ and $\mathrm{OH}^{-}$ions around DNA double helix at selected snapshots of the MD trajectory. The distributions of ions are displayed separately and all together. Solvent molecules have been omitted for clarity.

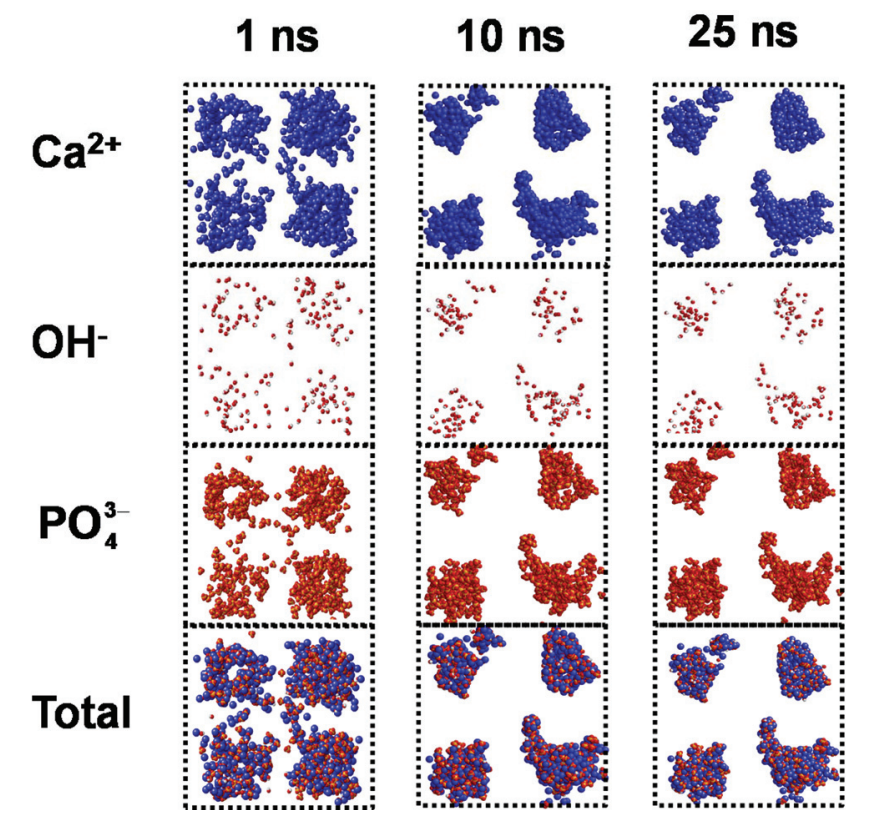

Fig. 2 Distribution of $\mathrm{Ca}^{2+}, \mathrm{PO}_{4}{ }^{3-}$ and $\mathrm{OH}^{-}$ions at selected snapshots of the MD trajectory in the absence of DNA. The distributions of ions are displayed separately and all together. Solvent molecules have been omitted for clarity.

formation of HAp. More specifically, the DNA double helix may behave as a nucleating motif that initially helps to nucleate amorphous-like calcium phosphate clusters, which subsequently tend to re-organize for transformation into HAp.

The templating role of the biomolecule in the nucleation of HAp is clearly evidenced when the distribution of inorganic ions is examined for the trajectory without DNA. Fig. 2 shows extensive inorganic clusters after $1 \mathrm{~ns}$, which is consistent with the formation of multiple nucleation centres for amorphous phosphate precipitation. This observation is consistent with nucleation from a supersaturated solution. In subsequent stages of the trajectory, these clusters grow similarly and ions tend to re-organize, suggesting that the system evolves towards poly-organized HAp. This multi-nucleation behaviour is fully consistent with previous studies devoted to investigating HAp crystal growth $^{28}$ and differs from that displayed in Fig. 1, which shows the preferential nucleation around the DNA template.

Fig. 3 compares the radial distribution functions of $\mathrm{P} \cdots \mathrm{P}$ pairs, $g_{\mathrm{P}-\mathrm{P}}(r)$, calculated for the crystal structure of natural HAp, ${ }^{29}$ the backbone of the DNA double helix and the $\mathrm{PO}_{4}{ }^{3-}$ anions in the inorganic solution with and without DNA. Thus, the trajectory of the inorganic solution with DNA was used to calculate the $g_{\mathrm{P}-\mathrm{P}}(r)$ of the DNA backbone (i.e. the double helix was preserved during the whole trajectory) and the $\mathrm{PO}_{4}{ }^{3-}$ anions. The $g_{\mathrm{P}-\mathrm{P}}(r)$ for the DNA shows a broad and high peak centred at $6.45 \AA$, which is consistent with the dynamics and structural regularity of the biomolecule. This peak contains the two peaks found for the HAp crystal at $r=6.2$ and $6.6 \AA$. However, as expected, none of the four characteristic peaks of HAp at $r \leq 5.4 \AA$ appears in the profile obtained for the 


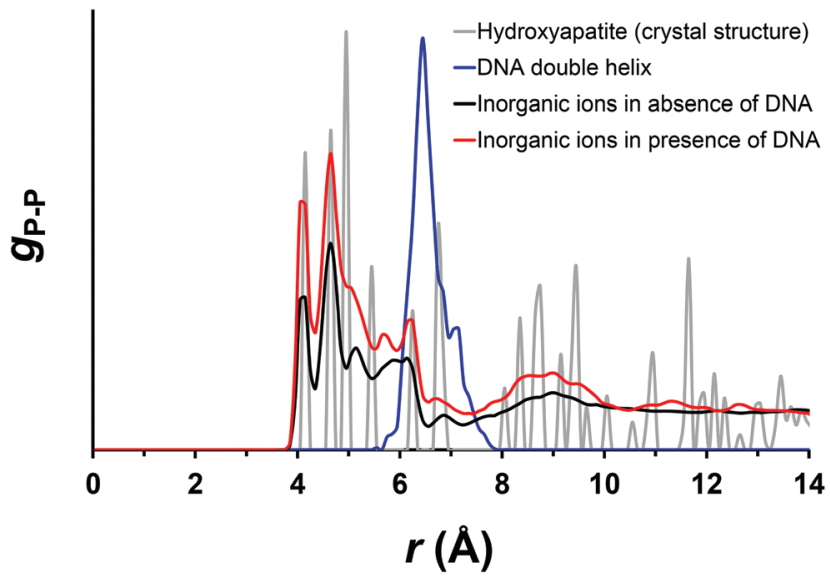

Fig. 3 Radial distribution functions of P...P atom pairs for: the crystal structure of natural HAp (grey line); the DNA double helix (blue line); the $\mathrm{PO}_{4}{ }^{3-}$ anions in the solution without DNA (black line); and the $\mathrm{PO}_{4}{ }^{3-}$ anions in the solution with DNA (red line). The profiles for DNA and $\mathrm{PO}_{4}{ }^{3-}$ anions were calculated using MD simulations performed in this work while the profile for natural HAp was obtained using the crystallographic coordinates reported in ref. 29.

biomolecule. This limitation is overcome in the $g_{\mathrm{P}-\mathrm{P}}(r)$ calculated for the $\mathrm{PO}_{4}{ }^{3-}$-containing solutions. Thus, all the peaks found at $r<6.7 \AA$ for the HAp crystal are identified in the profile derived for the inorganic solution with DNA. Furthermore, the six peaks found for the HAp crystal in the 8-10 interval fit within a broad peak that contains multiple shoulders. This is consistent with an ordered enlargement of the clusters. Although quantitative comparison of the two profiles still reveals some discrepancies (i.e. in the $g_{\mathrm{P}-\mathrm{P}}(r)$ derived from MD the peak at $r=4.9 \AA$ is a shoulder, the peak at $r=$ $5.4 \AA$ is shifted by $\sim 0.2 \AA$, and the intensity of the peak at $r=$ $6.7 \AA$ is low after $50 \mathrm{~ns}$ trajectory), the qualitative concordance clearly indicates that DNA favours the mineral formation or even crystallization of HAp around it.

The agreement between the profiles derived from the HAp crystal structure and the snapshots recorded from the MD trajectory in the absence of DNA is also very remarkable, even though the definition of the peaks in the latter is not very high. This should be attributed not only to the length of the trajectory (i.e. $25 \mathrm{~ns}$ only) but also to the organization mechanism discussed above, which is based on the simultaneous formation and growing of multiple clusters (nucleation centres).

Inspection of Fig. 4, which displays the radial distribution functions of $\mathrm{Ca} \cdots \mathrm{Ca}$ and $\mathrm{Ca} \cdots \mathrm{P}$ pairs $\left(g_{\mathrm{Ca}-\mathrm{Ca}}(r)\right.$ and $g_{\mathrm{Ca}-\mathrm{P}}(r)$, respectively) obtained for the crystal structure of natural HAp and the simulated systems, corroborates the role of DNA as a template. Thus, the similitude of the profiles derived from the trajectories in the presence and absence of DNA as well as the
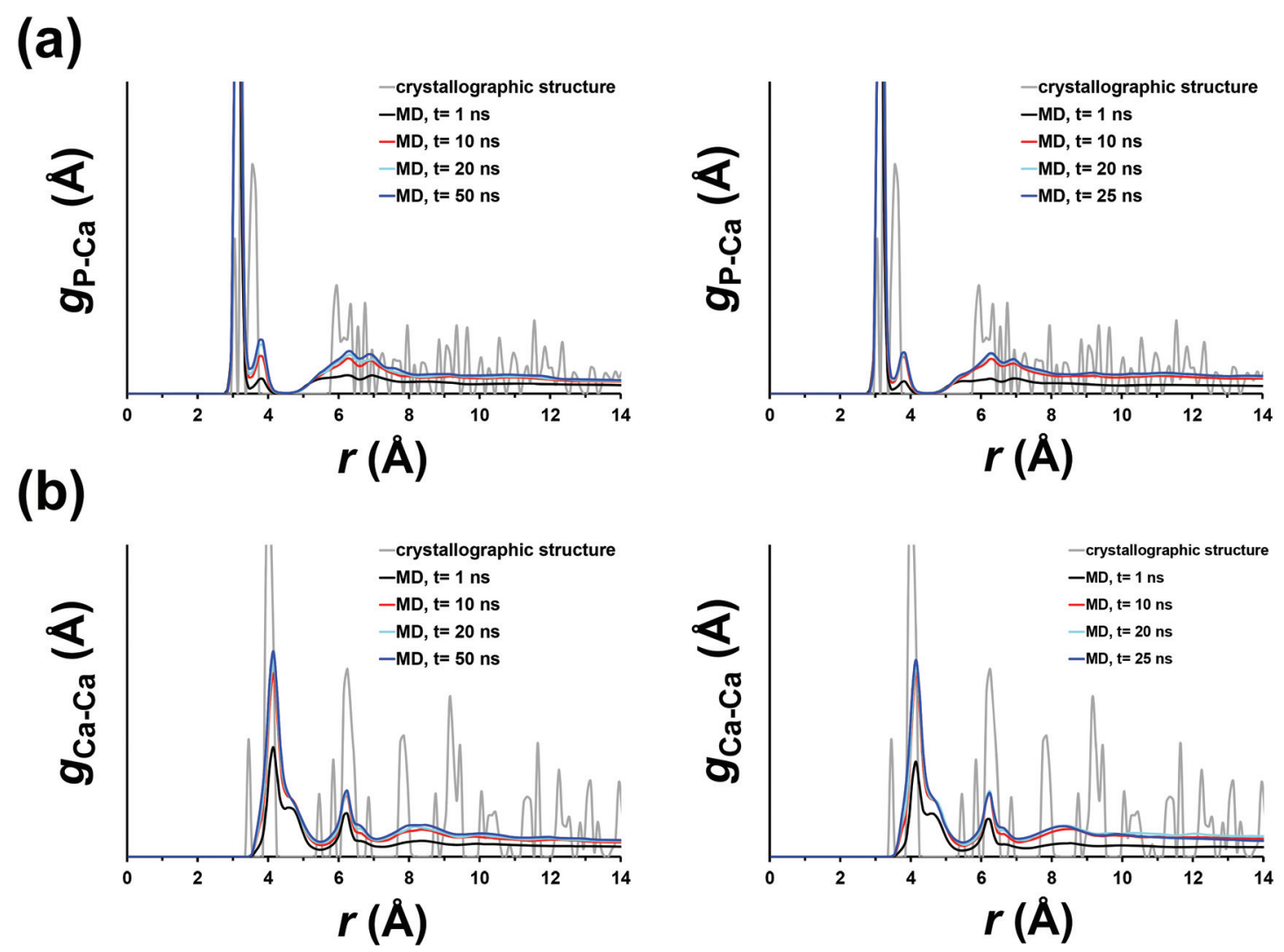

Fig. 4 Radial distribution functions of (a) P...Ca and (b) Ca ...Ca atom pairs calculated at different time intervals for the simulated inorganic solutions with and without DNA (left and right, respectively). The profile obtained using the crystallographic coordinates of natural HAp (grey line) has been included in all cases for comparison. 
rapid definition of such profiles (i.e. the profile remain practically invariant after $10 \mathrm{~ns}$ ) indicate that DNA does not inhibit the nucleation of HAp around it, as recently suggested. ${ }^{16}$ Indeed, the correspondence between the peaks derived from simulations and the peaks calculated using the crystallographic coordinates of HAp confirms that, after a few ns, the inorganic clusters tend to organize into pseudo-ordered structures.

As mentioned above, Fig. 1 and 2 suggest that the diffusion of $\mathrm{OH}^{-}$anions through the inorganic solution and their incorporation into the calcium phosphate clusters is the limiting step for the formation of HAp. To clarify this feature, the radial distribution functions of $\mathrm{Ca} \cdots \mathrm{OH}^{-}$and $\mathrm{OH}^{-} \cdots \mathrm{OH}^{-}$pairs $\left(g_{\mathrm{Ca}-\mathrm{OH}}(r)\right.$ and $g_{\mathrm{OH}-\mathrm{OH}}(r)$, respectively) for the simulated systems have been calculated (Fig. 5). Interestingly, comparison of the $g_{\mathrm{Ca}-\mathrm{OH}}(r)$ profiles derived from the simulations in the absence and presence of DNA indicates that, apparently, the diffusion of $\mathrm{OH}^{-}$is slower in the former than the in the latter. Thus, the height of the peaks found at $r$ values ranging from 4 to $7 \AA$ changes progressively during the simulation of the inorganic solution without DNA. In contrast, the peaks at such regions remain practically unchanged after $10 \mathrm{~ns}$ of $\mathrm{MD}$ when the biomolecule has been included in the simulation. The role of DNA as template is also reflected by the peak appearing in the $g_{\mathrm{Ca}-\mathrm{OH}}(r)$ profile after $40 \mathrm{~ns}$ at $3.1 \AA$ (Fig. 5 ). This peak gives evidence that $\mathrm{OH}^{-}$anions slowly diffuse towards the positions typically occupied at Hap, indicating that the biomolecule promotes, or at least does not inhibit, mineral growth. Similar features are concluded from the $g_{\mathrm{OH}-\mathrm{OH}}(r)$ profiles.

The diffusion of $\mathrm{OH}^{-}$during the MD simulation in the presence of DNA is clearly shown in Fig. 6, which represents the temporal evolution of the radial distribution function for $\mathrm{OH}^{-} \cdots \mathrm{P}(\mathrm{DNA})$ pairs, $g_{\mathrm{OH}-\mathrm{DNA}}(r)$. The profiles calculated at different time intervals provide information about the temporal evolution of the number and relative position of $\mathrm{OH}^{-}$ anions located at a distance smaller than $21 \AA$ from a phosphate group belonging to DNA. As can be seen, $\mathrm{OH}^{-}$anions progressively incorporate to different clusters during the whole simulation, reinforcing the hypothesis that their diffusion through the inorganic solution is the limiting step for the growth of the mineral structure. Fig. 7a depicts a representative calcium phosphate cluster obtained at the first stages of the simulation $(<1 \mathrm{~ns})$ without DNA. This formation of such simple clusters seems to be a requisite for the growth of HAp from inorganic solutions. Fig. $7 \mathrm{~b}$ and $7 \mathrm{c}$ show clusters involving $\mathrm{Ca}^{2+}, \mathrm{PO}_{4}{ }^{3-}$ and $\mathrm{OH}^{-}$ions from simulations without and with DNA, respectively, which suggest the nucleation of HAp.

The overall observation of the results reported in this section indicates that the DNA promotes the role of the double
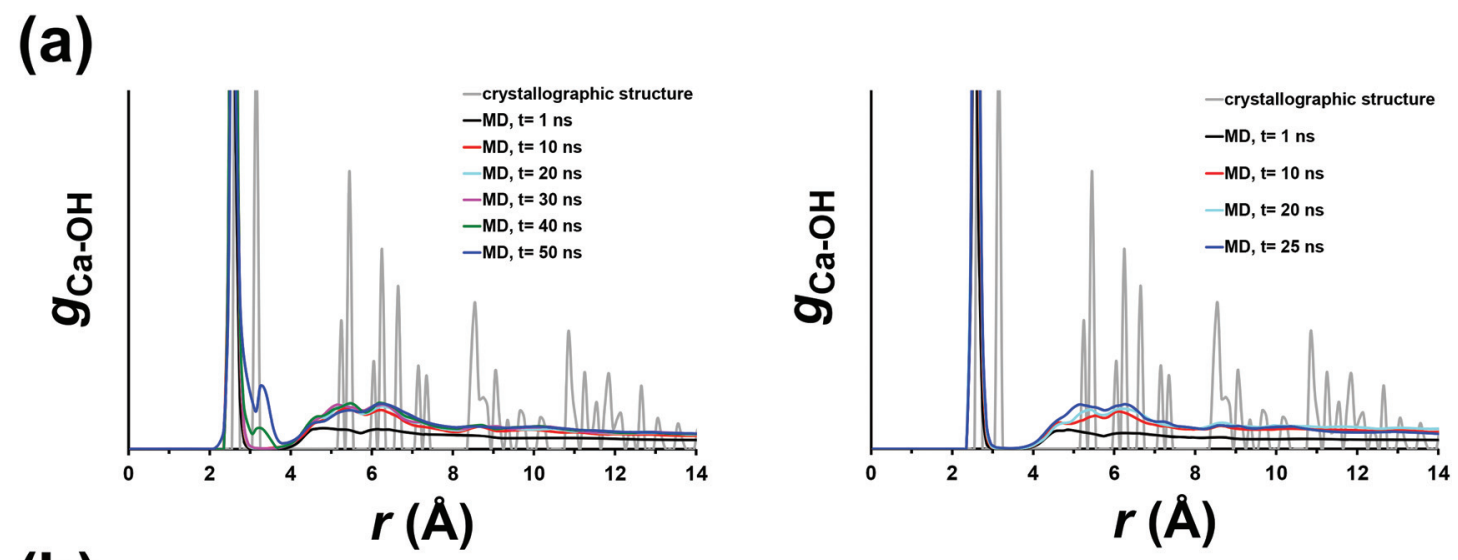

(b)
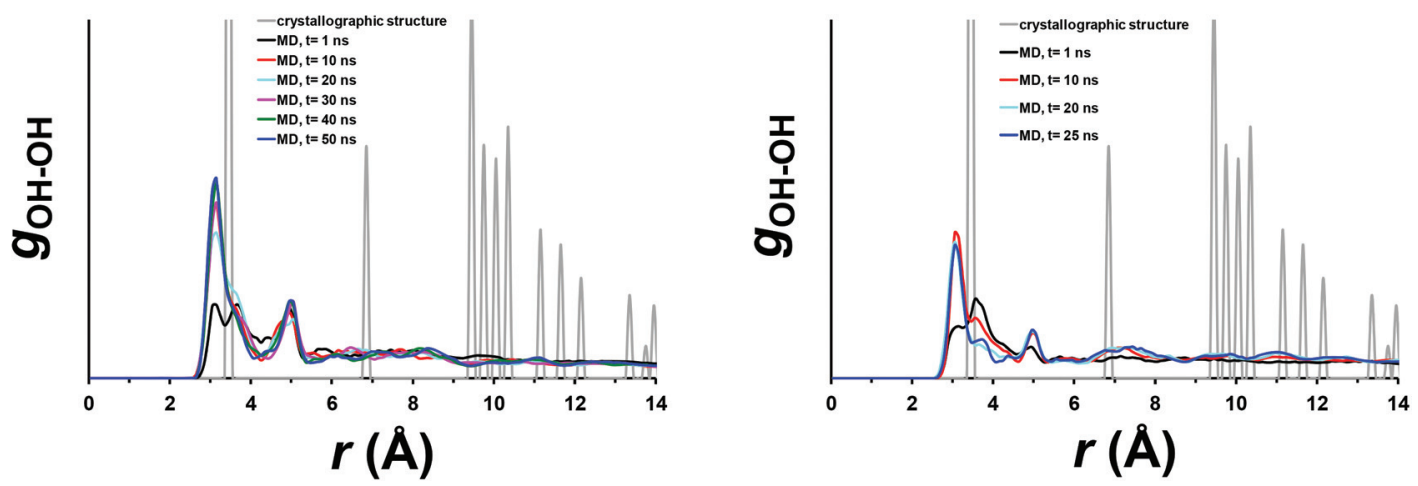

Fig. 5 Radial distribution functions of (a) $\mathrm{Ca} \cdots \mathrm{OH}^{-}$and (b) $\mathrm{OH}^{-} \ldots \mathrm{OH}^{-}$atom pairs calculated at different time intervals for the simulated inorganic solutions with and without DNA (left and right, respectively). The profile obtained using the crystallographic coordinates of natural HAp (grey line) has been included in all cases for comparison. 


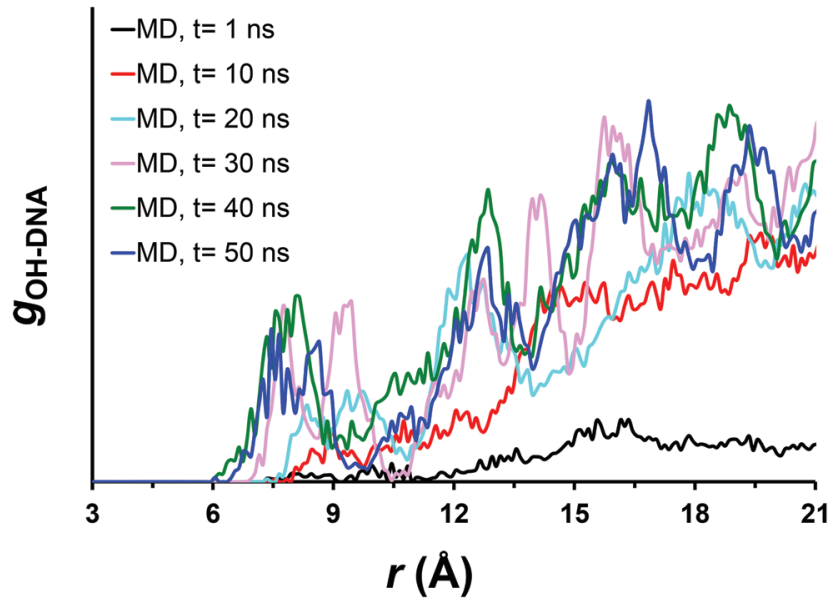

Fig. 6 Radial distribution functions of $\mathrm{OH}^{-}$...P pair, where $\mathrm{P}$ represents the phosphorous atom of DNA backbone, calculated at different time intervals for the simulated inorganic solution with DNA.

(a)

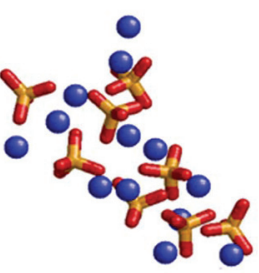

(c)

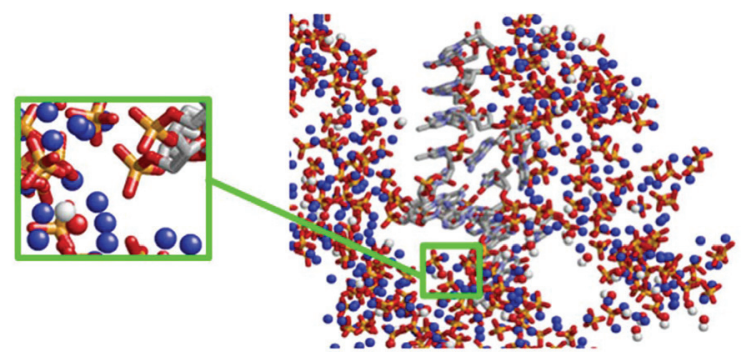

Fig. 7 (a) Representative calcium phosphate cluster obtained the first stages of the simulation without DNA. Representative clusters including $\mathrm{OH}^{-}$ions extracted from the simulation (b) without and (c) with DNA.

helix backbone as a template for the nucleation of HAp. The embryonic calcium phosphate clusters formed at the first stages of the simulation grow and transform into complex clusters, in which $\mathrm{Ca}^{2+}, \mathrm{PO}_{4}{ }^{3-}$ and $\mathrm{OH}^{-}$ions occupy positions that resemble those of crystalline HAp. This re-organization, which is largely influenced by the incorporation of $\mathrm{OH}^{-}$into the clusters, supports the benefit of the interaction between the DNA and the inorganic ions for the formation of HAp. Accordingly, experimental studies for the biomineralization of DNA into HAp have been conducted in the next section by mixing aqueous containing $\mathrm{Ca}^{2+}, \mathrm{PO}_{4}{ }^{3-}$ and $\mathrm{OH}^{-}$ions with DNA.

\section{Incorporation of DNA in HAp nanocapsules and nanocrystals}

Fig. 8 shows the morphologies of HAp samples prepared using $\mathrm{Ca}\left(\mathrm{NO}_{3}\right)_{2}, \quad\left(\mathrm{NH}_{4}\right)_{2} \mathrm{HPO}_{4}$ and fish sperm DNA in aqueous
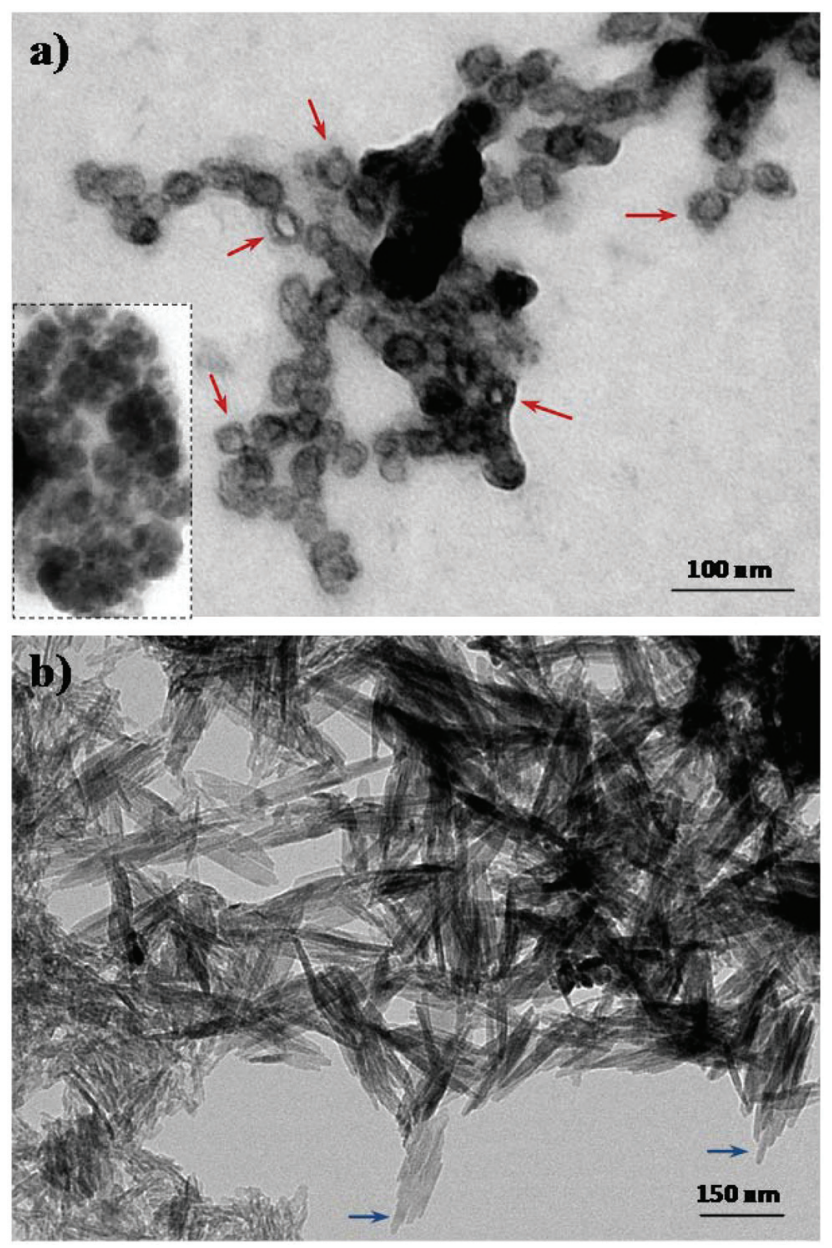

Fig. 8 TEM micrographs showing HAp-DNA nanocapsules (a) and nanocrystals (b). Red arrows point out capsules with a clearly distinctive contrast that suggest the incorporation of DNA in their inner part. For comparison purposes the inset shows nanocapsules prepared under the same experimental conditions but in absence of fish sperm DNA. Blue arrows emphasize the nanorods that constitute the crystal aggregates.

solution and under two well differentiated conditions based on previously established methodologies. ${ }^{30-32}$

In order to get nanocapsules the solutions containing $\mathrm{Ca}^{2+}$ and $\mathrm{PO}_{4}{ }^{3-}$ ions were quickly mixed at high $\mathrm{pH}$, which favoured rounded morphologies. Aggregation was avoided by adding a surfactant (CTAB), highly diluted solutions being used. DNA molecules should form micelles in solution that adsorbed $\mathrm{Ca}^{2+}$ ions on their surface by electrostatic interaction. ${ }^{32}$ After the addition of the $\mathrm{PO}_{4}{ }^{3-}$-containing solution, the reaction took place forming HAp around the initial DNA micelles. Fig. 8a clearly shows the presence of hollow nanospheres with a diameter close to $20 \mathrm{~nm}$, which may contain the DNA molecules inside. In contrast, solid nanospheres of similar size (inset of Fig. 8a) were obtained when DNA was not added to any of the initial inorganic solutions.

A high concentration of DNA was employed for the preparation of nanocrystals and, consequently, it was added to the $\mathrm{PO}_{4}{ }^{3-}$ solution instead of the $\mathrm{Ca}^{2+}$ one in order to avoid the 
formation of complexes that could limit solubility. The crystal anisotropy and, specifically, a preferred growth along the crystallographic $c$ axis were favoured by decreasing the $\mathrm{pH}$ to $10 .^{31}$ The phosphate solution was slowly added over the $\mathrm{Ca}^{2+}$ solution to avoid a rapid precipitation, allowing the development of well formed crystals from a primary nucleus. Fig. 8b shows the crystalline aggregates that were attained under these selected conditions. Aggregates had a length close to $2 \mu \mathrm{m}$ and a variable wideness that was found to depend on the number of constitutive nanorods, each with a width close to $20 \mathrm{~nm}$.

Different techniques (FTIR, XPS UV-vis and electrophoresis) have been applied to demonstrate the incorporation of DNA inside the nanocapsules/nanorods. Fig. 9 shows the FTIR spectra of synthesized HAp with typical $\mathrm{PO}_{4}{ }^{3-}$ bands at 1093 , 1033 and $962 \mathrm{~cm}^{-1}$ and any significant signal in the 1800-800 $\mathrm{cm}^{-1}$ region. The spectra of HAp nanocapsules prepared in the presence of DNA is significantly more complex, and multiple bands associated with the biomolecule can be distinguished with relatively high intensity. It should be remarked that the spectrum was recorded after removal of all superficially adsorbed DNA by digestion with deoxyribonuclease, signals of the included DNA being clearly detected because of the small thickness of the HAp wall. In particular, amide bands at 1653 and $1558 \mathrm{~cm}^{-1}$, phosphate bands at $1050 \mathrm{~cm}^{-1}$ and $\mathrm{NH}$ and methylene bands at 1480-1300, 1220-1210 and $890-840 \mathrm{~cm}^{-1}$. In contrast, the spectrum of

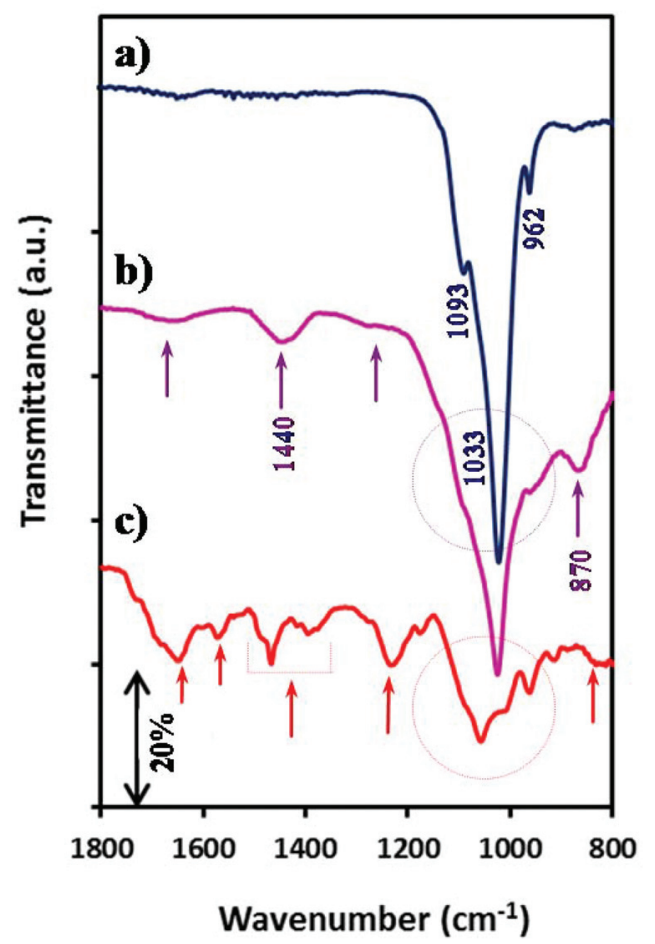

Fig. 9 FTIR spectra of HAp nanocapsules (a), HAp-DNA nanocrystals (b) and HAp-DNA nanocapsules (c). Nanocapsules prepared in presence of fish sperm DNA were previously digested with deoxyribonuclease to eliminate adsorbed DNA. Arrows and circles point out DNA distinctive signals and the complex phosphate region, respectively. nanorods was less clear even before the treatment with deoxyribonuclease. In this case, interpretation was more difficult due to the overlapping of carbonate bands at 1440 and $870 \mathrm{~cm}^{-1}$ that were a consequence of dissolved $\mathrm{CO}_{2}$ from the atmosphere during the synthesis and a typical carbonate substitution of phosphate anions. Furthermore, it seems that the DNA incorporated inside nanorods could not be detected by FTIR due to presence of an opaque and thick HAp wall. Nevertheless, small signals around 1653 and $1220-1210 \mathrm{~cm}^{-1}$ could be envisaged and the phosphate band becomes broader with respect to that observed in the HAp spectrum.

Fig. 10 depicts the characteristic XPS spectra in the P2p, Ca2p and N1s regions for HAp and HAp-DNA after the enzymatic digestion. The $\mathrm{P} 2 \mathrm{p}$ and $\mathrm{Ca} 2 \mathrm{p}$ peaks obtained before and after deconvolution, which are practically identical for the two systems, are in full agreement with those reported in the literature for natural HAp. The Ca2p spectra present a doublet with $\mathrm{Ca} 2 \mathrm{p}_{3 / 2}$ and $\mathrm{Ca} 2 \mathrm{p}_{1 / 2}$, which is typically found for $\mathrm{Ca}^{2+}$ in inorganic calcium-oxygen compounds with binding energy at $347 \mathrm{eV}$ and $351 \mathrm{eV}$, respectively. ${ }^{33}$ Also, the single P2p peak centred at $133 \mathrm{eV}$ originates from the $\mathrm{PO}_{4}{ }^{3-}$ anions of HAp nanocrystals. ${ }^{33,34}$ As was expected, the N1s signal is completely absent in HAp. In contrast, HAp-DNA samples digested with deoxyribonuclease to eliminate the DNA adsorbed onto the surface of the nanoparticles show a band centred at $400 \mathrm{eV}$, which has been attributed to the encapsulated biomolecule.

UV-vis spectra, which are displayed in Fig. 11, clearly demonstrate the presence of DNA molecules in both nanocapsules and nanorod preparations since a characteristic absorption peak at $260 \mathrm{~nm}$ was detected in both cases. This absorbance increases after dissolution of the sample with the acid medium, as expected for DNA molecules encapsulated inside the HAp nanoparticles. It should be emphasized that such an increment is very remarkable in the nanorod preparation, corroborating the shielding effect hypothesis discussed above. Fig. 11 also shows the spectra of digested samples. As expected, the absorbance at $260 \mathrm{~nm}$ decreases considerably after enzymatic treatment, reaching a practically zero value for the nanorod sample. However, the significant absorbance detected after dissolution of the sample in acid medium unambiguously demonstrates the incorporation of DNA inside nanoparticles.

The quantification of DNA in nanoparticles was performed for the nanorod preparation due to a greater amount of sample being available. For this purpose, the absorbance measurement $\left(A_{260}\right)$ was multiplied by the well-known conversion factor of $50 \mu \mathrm{g} \mathrm{mL} \mathrm{m}^{-1}$ (for double-strand DNA) to get the total amount of DNA. Results indicate that approximately $11 \mu \mathrm{g}$ and $33 \mu \mathrm{g}$ of DNA are adsorbed on the surface or encapsulated inside the $1 \mathrm{mg}$ of HAp nanorods, respectively. Accordingly, an encapsulating efficiency close to $25 \%$ is derived, considering that the DNA/HAp ratio from synthesis was $127 \mu \mathrm{g} \mathrm{mg}^{-1}$.

Similar conclusions are derived from the electrophoretic pattern of HAp/DNA nanorods that is displayed in Fig. 12. Both the DNA superficially adsorbed and that incorporated 

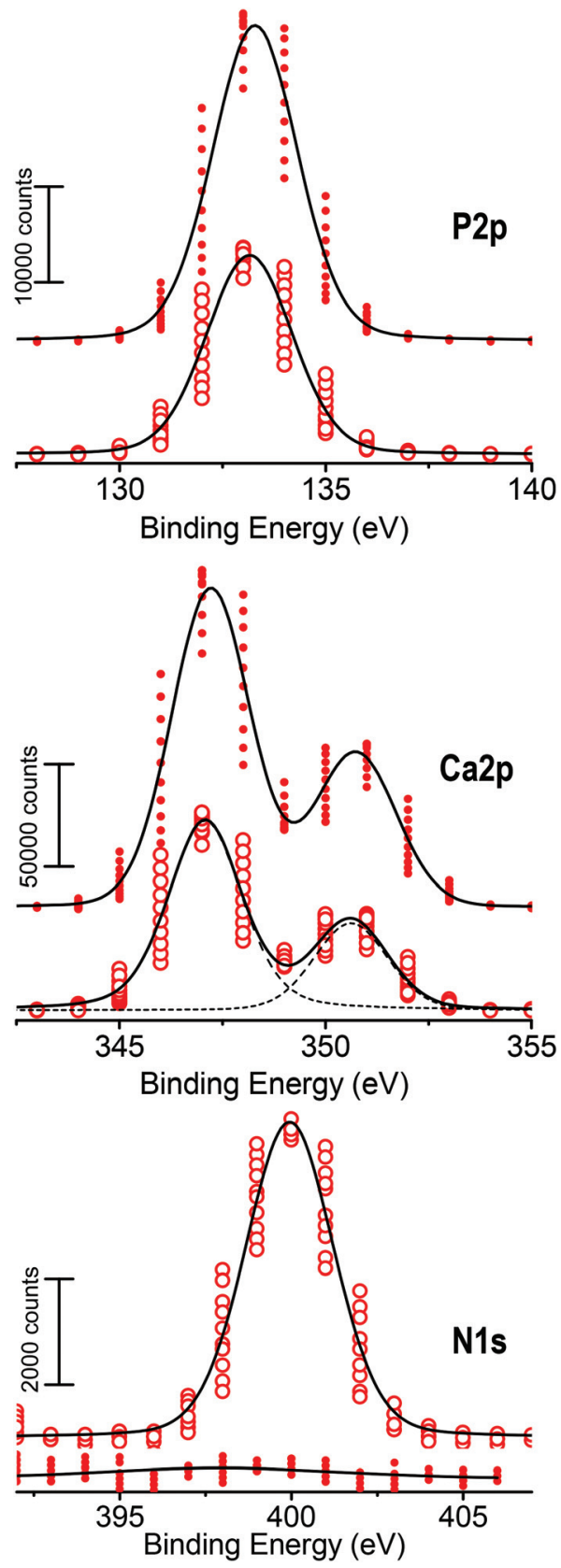

Fig. 10 High-resolution XPS spectra for HAp (solid circles) and HApDNA (open circles) nanocapsules: P2p, Ca2p and N1s regions. HAp-DNA samples were previously submitted to enzymatic digestion with deoxyribonuclease to eliminate the DNA adsorbed onto the surface.

inside the particles give rise to the high intense spot observed on lane 4. This corresponds to the particles digested with EDTA, which is capable of chelating calcium ions. The intensity of the latter spot is clearly higher than that observed for the spot of lane 3 , which refers to the initially loaded particles (i.e. it is basically attributed to both DNA adsorbed on the surface and DNA internally loaded but able to migrate). The fluorescence observed in the wells of lanes 3 and 4, and even the continuous smear, reflect the restricted mobility of DNA in the gel, which is caused by a progressive release from the bigger particles. Lanes 5 and 6 correspond to particles in which the adsorbed DNA was previously digested with deoxyribonuclease to eliminate this superficial DNA. A high intense spot is observed after dissolution with EDTA (lane 6) while a low signal is detected before dissolution (lane 5), as expected for encapsulated DNA. Finally, Fig. 12 points out that the intensity of the DNA spot of lane 4 results from the addition of the signals of DNA adsorbed in the surface (lane 3) and DNA incorporated inside the particle (lane 6).

\section{Conclusions}

Classical MD simulations of inorganic $\mathrm{Ca}^{2+}, \mathrm{PO}_{4}{ }^{3-}$ and $\mathrm{OH}^{-}$ aqueous solutions in the presence and absence of DNA have shown that the biomolecule acts as a template for the nucleation and growth of HAp. This templating effect of DNA is accompanied by a change in the aggregation mechanism. Thus, simulations show the formation of multiple calcium phosphate clusters in the absence of DNA, which incorporate $\mathrm{OH}^{-}$anions after some ns transforming into nucleation centres for the formation of HAp. The simultaneous formation of multiple nucleation centres is fully consistent with the mechanism typically found for the crystallization of inorganic salts from their solutions. In contrast, simulations in the presence of the biomolecule reveal that calcium phosphate clusters are formed surrounding the DNA backbone. The phosphate groups of the biomolecule act as a very large nucleus for the growth of the HAp. As occurs in the absence of DNA, the formation of HAp around DNA is limited by the incorporation of $\mathrm{OH}^{-}$anions to the cluster. In summary, MD simulations clearly indicate that DNA promotes the templated nucleation of $\mathrm{HAp}$ from a Ca ${ }^{2+}, \mathrm{PO}_{4}{ }^{3-}$ and $\mathrm{OH}^{-}$-containing inorganic solution. These conditions have been experimentally applied in the laboratory to create nanoparticles and nanocrystals with DNA inside. Nanoparticles show a spherical shape and a diameter of $\sim 20 \mathrm{~nm}$ while nanocrystals are constituted of nanorods with a width of $\sim 20 \mathrm{~nm}$. After removal of all superficially adsorbed DNA by digestion with deoxyribonuclease, the presence of DNA inside nanospheres and nanocrystals has been unambiguously determined by FTIR, XPS, UV-vis and gel electrophoresis. The biomineralization of DNA is particularly important for biomedical applications requiring the protection of the biomolecule from aggressive environmental conditions.

\section{Acknowledgements}

This work was supported by B. Braun Surgical S.A. through a joint research agreement with UPC. Special thanks to $\mathrm{Mr}$ M. Jiménez for believing in the idea and funding the project. Authors thank J.F. Julián, J. Navinés, J.R. Grifols, C. Colomer, L.F. del Castillo, S. Santos and J.M. Turon for their contributions to the conceptual framework of the work. This work is integrated within a wider research project supported by B. Braun Surgical S.A., UPC, Institut de Ciencies Fotòniques 

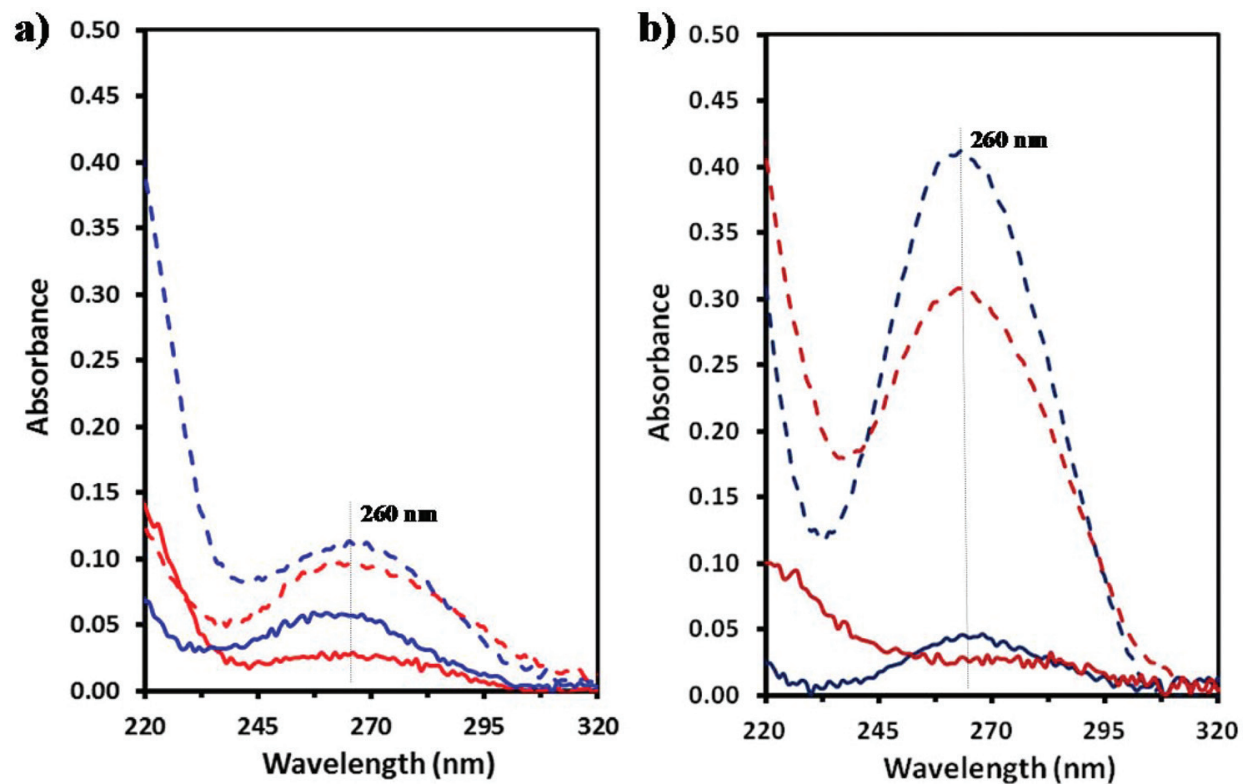

Fig. 11 UV-vis absorption spectra of the aqueous solution/dispersion of HAp-DNA nanocapsules (a) and nanocrystals (b) (with blue traces). Spectra from samples digested with deoxyribonuclease to eliminate adsorbed DNA are indicated with red traces, whereas those corresponding to samples dissolved with the acid medium are indicated with dashed traces.

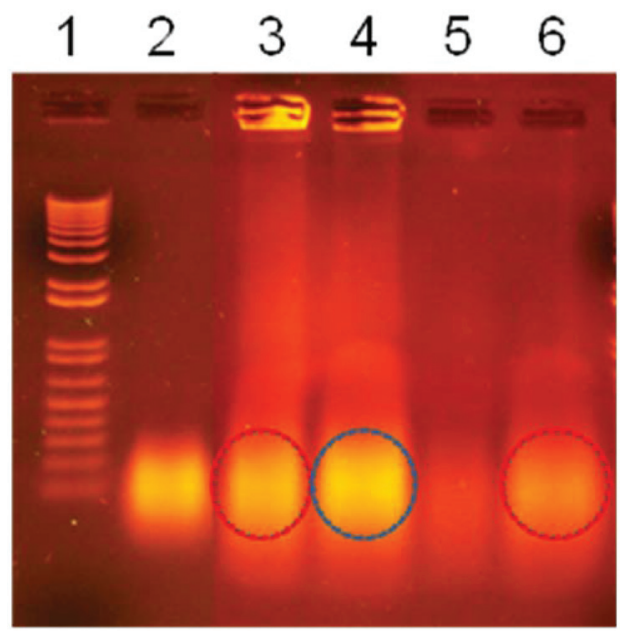

Fig. 12 Electrophoretic pattern of HAp-DNA nanocrystals. Lane 1: molecular weight marker. Lane 2: Fish sperm DNA. Lane 3: HAp-DNA nanocrystals. Lane 4: HAp-DNA nanocrystals dissolved with EDTA. Lane 5: HAp-DNA nanocrystals digested with deoxyribonuclease. Lane 6: HAp-DNA nanocrystals digested with deoxyribonuclease and then dissolved with EDTA. Note that the intensity of the DNA signal in lane 4 (blue circle) is similar to the addition of the intensity of DNA signals in lanes 3 and 6 (red circles).

(ICFO), and the Institut Català de la Salut (ICS) through the H. U. Germans Trias I Pujol and H. U. Vall d'Hebron, MICINN-FEDER funds (MAT2012-34498 and MAT2012-36205), and by the Generalitat de Catalunya (2009SGR925, 2009SGR1208 and XRQTC). The authors are indebted to the Centre de Supercomputació de Catalunya (CESCA) for computational facilities. Support for the research of C.A. was received through the "ICREA Academia".

\section{References}

1 T. S. B. Narasaraju and D. E. Phebe, J. Mater. Sci., 1996, 31, $1-21$.

2 S. Weiner and H. D. Wagner, Annu. Rev. Mater. Sci., 1998, 28, 271-298.

3 P. Fratzl, H. S. Gupta, E. P. Paschalis and P. Roschger, J. Mater. Chem., 2004, 14, 2115-2123.

4 M. Tirrell, E. Kokkoli and M. Biesalski, Surf. Sci., 2002, 500, 61-83.

5 A. George and A. Veis, Chem. Rev., 2008, 108, 4670-4693.

6 A. L. Boskey, Connect. Tissue Res., 2003, 44, 5-9.

7 A. I. Alford and K. D. Hankenson, Bone, 2006, 38, 749757.

8 A. L. Boskey, Bone mineralization, in Bone Mechanics Handbook, ed. S. C. Cowin, CRC Press, Boca Raton, 2nd edn, 2000, pp. 5.1-5.31.

9 R. Baker, K. D. Rogers, N. Shepherd and N. Stone, British J. Cancer, 2010, 103, 1034-1039.

10 S. H. Zhu, B. Y. Huang, K. C. Zhou, S. P. Huang, F. Liu, Y. M. Li, Z. G. Xue and Z. G. Long, J. Nanoparticle Res., 2004, 6, 307-311.

11 D. Kozlova, S. Chernousova, T. Knuschke, J. Buer, A. M. Westendorf and M. Epple, J. Mater. Chem., 2012, 22, 396-404.

12 S. Bisht, G. Bhakta, S. Mitra and A. Maitra, Int. J. Pharm., 2005, 288, 157-168.

13 D. Olton, J. Li, M. E. Wilson, T. Rogers, J. Close, L. Huang, P. N. Kumta and C. Sfeir, Biomaterials, 2007, 28, 12671279.

14 M. Brundin, D. Figdor, G. Sundqvist and U. Sjögren, J. Endod., 2013, 39, 211-216. 
15 M. Jordan, A. Schallhorn and F. M. Wurm, Nucleic Acids Res., 1996, 24, 596-601.

16 M. Okazaki, Y. Yoshida, S. Yamaguchi, M. Kaneno and J. C. Elliot, Biomaterials, 2001, 22, 2459-2464.

17 G. Revilla-López, J. Casanovas, O. Bertran, P. Turón, J. Puiggalí and C. Alemán, Biointerphases, 2013, 8, 10-25.

18 K. Grzeskowiak, D. S. Goodsell, M. Kaczor-Grzeskowiak, D. Cascio and R. E. Dickerson, Biochemistry, 1993, 32, 8923-8931.

19 J. C. Phillips, R. Braun, W. Wang, J. Gumbart, E. Tajkhorshid, E. Villa, C. Chipot, R. D. Skeel, L. Kale and K. Schulten, J. Comput. Chem., 2005, 26, 1781-1802.

20 W. D. Cornell, P. Cieplak, C. I. Bayly, I. R. Gould, K. M. Merz, D. M. Ferguson, D. C. Spellmeyer, T. Fox, J. W. Caldwell and P. A. Kollman, J. Am. Chem. Soc., 1995, 117, 5179-5197.

21 Y. Duan, S. Chowdhury, M. C. Lee, G. Xiong, W. Zhang, R. Yang, P. Cieplak, R. Luo, T. Lee, J. Caldwell, J. Wang and P. A. Kollman, J. Comput. Chem., 2003, 24, 1999-2012.

22 V. Hornak, R. Abel, A. Okur, B. Strockbine, A. Roitberg and C. Simmerling, Proteins, 2006, 65, 712-725.

23 G. M. Bradbrook, T. Gleichmann, S. J. Harrop, J. Habash, J. Raftery, J. Kalb, J. Yariv, I. H. Hillier and J. R. Helliwell, J. Chem. Soc., Faraday Trans., 1998, 94, 1603-1611.
24 W. L. Jorgensen, J. Chandrasekhar, J. D. Madura, R. W. Impey and M. L. Klein, J. Chem. Phys., 1983, 79, 926-935.

25 T. Darden, D. York and L. Pedersen, J. Chem. Phys., 1993, 98, 10089-10092.

26 H. J. C. Berendsen, J. P. M. Postma, W. F. van Gunsteren, A. DiNola and J. R. Haak, J. Chem. Phys., 1984, 81, 36843690.

27 J. P. Ryckaert, G. Ciccotti and H. J. C. Berendsen, J. Comput. Phys., 1977, 23, 327-341.

28 J. H. Harding, D. M. Duffy, M. L. Sushko, P. M. Rodger, D. Quigley and J. A. Elliot, Chem. Rev., 2008, 108, 48234854.

29 J. M. Hiughes, M. Cameron and K. D. Corwley, Am. Mineral., 1989, 74, 870-876.

30 Y. Zhang and J. Lu, J. Nanopar. Res., 2007, 9, 589-594.

31 P. Wang, C. Li, H. Gong, X. Jiang, H. Wang and K. Li, Powder Technol., 2010, 203, 315-321.

32 C. Qi, Y.-J. Zhu, B.-Q. Lu, X.-Y. Zhao, J. Zhao and F. Chen, J. Mater. Chem., 2012, 22, 22642-22650.

33 Handbook of X-ray Photoelectron Spectroscopy, ed. J. F. Moulder, J. Chastain, Physical Electronics Division, Perkin-Elmer Corporation, 1995.

34 M. C. Chang and J. Tanaka, Biomaterials, 2002, 23, 38793885. 